\title{
Effect of Hydrogen Peroxide in the Growth of Yellow Passion Fruit Seedlings Under Salinity Stress
}

\author{
Adriana da S. Santos ${ }^{1}$, Railene H. C. R. Araújo ${ }^{1}$, Reginaldo G. Nobre ${ }^{1}$, Valéria F. de O. Sousa ${ }^{1}$, \\ Marília H. B. S. Rodrigues ${ }^{1}$, Juliana A. Formiga ${ }^{1}$, Fernando A. L. Gomes ${ }^{1}$, Gisele L. $\operatorname{dos}_{\text {Santos }^{1}} \&_{\text {E }}$ Eny A. Onias ${ }^{1}$ \\ ${ }^{1}$ Academic Unit of Tropical Horticulture, Federal University of Campina Grande, Pombal, PB, Brazil \\ Correspondence: Valéria F. de O. Sousa, Academic Unit of Tropical Horticulture, Federal University of Pombal, \\ Paraíba, Brazil. Tel: 55-083-999-431-191. E-mail: valeriafernandesbds@gmail.com
}

$\begin{array}{lcc}\text { Received: May 23, 2018 } & \text { Accepted: July 4, } 2018 & \text { Online Published: September 15, } 2018 \\ \text { doi:10.5539/jas.v10n10p151 } & \text { URL: https://doi.org/10.5539/jas.v10n10p151 }\end{array}$

\begin{abstract}
Hydrogen peroxide $\left(\mathrm{H}_{2} \mathrm{O}_{2}\right)$ is a molecule that can flag plants under biotic and abiotic stress conditions. Among the kinds of stress, the salinity stress is the one that most usually affects plants. Consequently, the purpose hereof was to use hydrogen peroxide $\left(\mathrm{H}_{2} \mathrm{O}_{2}\right)$ to mitigate the possible harmful effects of salinity in yellow passion fruit seedlings. We employed a randomized block design, in a $5 \times 3$ factorial scheme, corresponding to five irrigation water electric conductivity levels $\left(0.3 ; 1.3 ; 2.3 ; 3.3\right.$; and $\left.4.3 \mathrm{dS} \mathrm{m}^{-1}\right)$ and three hydrogen peroxide concentrations $\left(0 ; 5\right.$; and $\left.15 \mu \mathrm{mol} \mathrm{L}^{-1}\right)$, with four repetitions. The treatments were applied foliarly 7 and 15 days after the seedlings' germination with hand sprayers. Sixty days after sowing, we evaluated the seedlings' growth and quality variables, which finally proved that hydrogen peroxide mitigates the harmful effect of the irrigation water's salinity up to $2 \mathrm{dS} \mathrm{m}^{-1}$ in the growth of yellow passion fruit seedlings at the concentration of $5 \mu \mathrm{mol} / \mathrm{L}$. Nonetheless, excessive concentrations $\left(15 \mu \mathrm{mol} \mathrm{L}^{-1}\right)$ associated with high salt concentrations were proven detrimental to the seedlings' phenological growth and quality.
\end{abstract}

Keywords: Passiflora edulis, $\mathrm{H}_{2} \mathrm{O}_{2}$, salinity

\section{Introduction}

In Brazil, pomology plays a very important economic and social role in every region of the country: it creates jobs, contributes for the human fixation in the field and for the distribution of the regional income, and it presents promising expectations of internal and external market (Agrianual, 2015).

The yellow passion fruit stands out from all other fruit trees of great expressiveness grown in the country, with the production of around 838,244 tons of fruits in 58,089 ha in the harvest of 2014/2015, which ensured to Brazil the title of the greatest world passion fruit producer. Its significant economic importance to the country is related to the fact that its juice is highly accepted in the international market, and to the fact that the fruit supplies the national market (Faleiro, Junqueira, \& Braga, 2008). Nevertheless, the absence of proper handling, lack of cultural cares, and nutritional deficiencies hinder the passion fruit to achieve an excellence level in production for exportation in Brazil (Campos et al., 2013).

In spite of the fact that the Northeast region has proper conditions for the culture's development and the greatest production in the country, it has a yielding of 12.42 ton/ha (IBGE, 2015), which may be mainly related to the region's water deficiency during most of the year, making the producers employ low-quality water for irrigation, which contains high salt levels.

The use of water with high salt concentrations for irrigation reduces the growth and development of sensitive plants, such as the passion fruit tree (Nunes et al., 2016), hindering the development of its maximum potential due to the abiotic stress caused by the excess of salts, which reduces the plant's water absorption level, and causes nutritional unbalance and toxicity due to specific ions (Willadino \& Câmara, 2010).

Many are now searching for technologies that can mitigate the salinity's effects to explore fields irrigated with salinity restrictions and/or use of salt water in agriculture to achieve economically viable productions, even in places with elevated ionic contents (Dias, Cavalcante, Leon, Santos, \& Albuquerque, 2011; Sá, Mesquita, Bertino, Costa, \& Araújo, 2015). Among these technologies, researchers are studying the use of substances that flag the plant's stress and gradually make the vegetable tolerant. 
In salinity stress situations, the accumulation of $\mathrm{Na}^{+}$and $\mathrm{Cl}^{-}$ions in vegetable tissues changes the plant's metabolism, causing, for example, the excessive production of reactive oxygen species (ROS) and consequently the plant's oxidative stress. To mitigate the damages caused by the excess of ROS in the most different cellular compartments, through the balance maintenance between production and elimination, and to maintain the cell's homeostasis, the plants have an enzymatic system composed of superoxide dismutase (SOD), ascorbate peroxidase (APX), and catalase (CAT) enzymes. The SOD, in response to stress, dismutates superoxide ions generating hydrogen peroxide $\left(\mathrm{H}_{2} \mathrm{O}_{2}\right)$, which is dismutated in water $\left(\mathrm{H}_{2} \mathrm{O}\right)$ and $\mathrm{O}_{2}$ through the CAT. Ergo, the exogenous application of $\mathrm{H}_{2} \mathrm{O}_{2}$ in a proper amount can cooperate in the response changes of the antioxidant protective system's enzymes, contributing to the increase of the plant's tolerance to salinity stress (Taiz, Zeiger, Moller, \& Murphy, 2017; Silveira, S. L. F. Silva, E. N. Silva, \& Viégas, 2016).

According to Gondim, Gomes Filho, Marques, and Prisco (2011), the application of $\mathrm{H}_{2} \mathrm{O}_{2}$ has been proven as an efficient salinity stress mitigator, while Silva, Lacerda, Medeiros, Souza, and Pereira (2016) reported that $\mathrm{H}_{2} \mathrm{O}_{2}$ is the viable way to acclimatize a plant exposed to an abiotic stress source because it makes the intracellular region activate the plant's defense responses to the stress caused by the excess of salts, resulting in cross-tolerance.

Additionally, according to Petrov and Van Breusegem (2012), $\mathrm{H}_{2} \mathrm{O}_{2}$ works as a regulator of several biologic process, such as the strengthening of the cell wall, senescence, photosynthesis, stomatal opening, and cell cycle. Nonetheless, the biologic effects of $\mathrm{H}_{2} \mathrm{O}_{2}$ were proven dependent both of its concentration and of its production site, as well as of the plant's developing stage and previous exposition to other types of stress.

Consequently, purpose hereof was to evaluate the use of hydrogen peroxide as a mitigator of the salinity stress caused by the irrigation water in yellow passion fruit seedlings at their initial stage of growth.

\section{Material and Methods}

The experiment was developed in a greenhouse of the Federal University of Campina Grande's Agri-food Science and Technology Center, Pombal Campus (PB), in the period of September to November 2017.

The treatments were arranged in an experimental design of randomized block, in a $5 \times 3$ factorial scheme, corresponding to five irrigation water electric conductivity levels [(control 0.3$) ; 1.3 ; 2.3 ; 3.3$; and $\left.4.3 \mathrm{dS} \mathrm{m}^{-1}\right]$ and three hydrogen peroxide concentrations [(control 0); 5 ; and $\left.15 \mu \mathrm{mol} \mathrm{L}^{-1}\right]$ applied through foliar pulverizations, with four repetitions, totalizing 60 experimental units, where each sample unit consisted in one plant. The salinity levels were defined based on the water samples used to irrigate the region.

The sowing was performed in black polyethylene bags with a capacity of 1.2 liter, which were filled with the mixture of soil, sand, and cattle manure in the proportion of 3:1:1, whose chemical characteristics are found in Table 1. Three yellow round passion fruit seeds, of the top seed brand, were sown per bag, at a depth of $1 \mathrm{~cm}$. The thinning process was performed 15 days after the seedlings' germination, remaining only the most vigorous one.

Table 1. Chemical characteristics of the substrate used to fill the bags. Pombal, CCTA/UFCG, 2017

\begin{tabular}{|c|c|c|c|c|c|c|c|}
\hline \multirow{2}{*}{ Textural classification } & \multirow{2}{*}{ Organic matter } & \multirow{2}{*}{$\mathrm{pH}\left(\mathrm{H}_{2} \mathrm{O}\right)$} & \multirow{2}{*}{$\mathrm{P}$} & \multicolumn{4}{|c|}{ Sortive complex } \\
\hline & & & & $\mathrm{Ca}^{2+}$ & $\mathrm{Mg}^{2+}$ & $\mathrm{Na}^{+}$ & $\mathrm{K}^{+}$ \\
\hline \multirow[b]{2}{*}{ Sandy franc } & ------ $\mathrm{g} \mathrm{kg}^{-1}$------ & & -- $\mathrm{mg} \mathrm{dm}^{-3}$-- & - - = & ----- cn & $\mathrm{dm}^{-3}$ & - n \\
\hline & 4.79 & 6.5 & 36.6 & 1.2 & 0.71 & 0.07 & 14.36 \\
\hline
\end{tabular}

The hydrogen peroxide $\left(\mathrm{H}_{2} \mathrm{O}_{2}\right)$ solutions were prepared through the dilution of pure peroxide at $99 \%$ in the respective studied concentrations. The application was performed at the end of the afternoon 7 and 15 days after the plants' germination, with the assistance of a hand sprayer, whose solution was applied directly on the leaves until they were completely moist.

The water samples, with their respective conductivity levels, were prepared through the addition of $\mathrm{NaCl}$ to the supply water (of $0.3 \mathrm{dS} \mathrm{m}^{-1}$ ) until the desired levels of wEC were obtained, which were measured with the assistance of a portable conductivity meter; said solutions were stored in $30 \mathrm{~L}$, duly protected to avoid evaporation and contamination with materials that might compromise their functionality plastic containers, one for each wEC level evaluated.

The irrigations with salt water begun 16 days after germination (DAG) and were performed every day to keep the soil's humidity close to its maximum retaining capacity, according to the drainage lysimeter method, whose 
applied depth receives the addition of a leaching fraction of $15 \%$. The volume applied $\left(\mathrm{V}_{\mathrm{a}}\right)$ by container was obtained by the difference between the previous volume $\left(\mathrm{V}_{\text {prev }}\right)$ applied less the mean of drainage (d) divided by the number of containers (n), as indicated in Equation 1:

$$
V_{a}=\frac{V_{\text {prev }}-(d / n)}{(1-F L)}
$$

Sixty days after sowing (DAS), the following variables were evaluated: Plant Height (PH): measured with the assistance of a ruler graduated in millimeters from the ground level to the insertion point of the last leaf; Leaf number $(\mathrm{LN})$ : by counting the leaves that presented a length above $1 \mathrm{~cm}$; Leaf area $\left(\mathrm{LA} \mathrm{cm}^{2}\right)$ : calculated through the equation: $\mathrm{LA}=0.1525+0.8134 * \mathrm{~L} * \mathrm{~W}$, where $\mathrm{L}=$ Length and $\mathrm{W}=$ Width, according to Schmildt, Oliari, Schmildt, Alexandre, Pires et al. (2016); Stem Diameter (SD): with the assistance of a digital caliper (graduated in $\mathrm{mm}$ ), whose measurement was performed at the plant's base at $1 \mathrm{~cm}$ above the soil; Root length (RL); Leaf, stem, and root dry mass (LDM, SDM, and RDM): obtained after washing and drying the different parts of the plants in a muffle with forced ventilation at a temperature of $65^{\circ} \mathrm{C}$, until constant mass was obtained; Total dry mass (TDM): through the sum of the aerial part dry mass and the root dry mass; Dickson quality index (DQI): which was determined according to the variables height, stem diameter, total, aerial part, and root dry biomass, according to Dickson, Leaf, Hosner (1960) through Equation 2:

$$
D Q I=\frac{T D M}{\left(\frac{P H}{S D}\right)+\left(\frac{D M A P}{R D M}\right)}
$$

Where, TDM = Total dry mass $(\mathrm{g}) ; \mathrm{PH}=$ Plant Height $(\mathrm{cm}) ; \mathrm{SD}=$ Stem Diameter $(\mathrm{mm})$; DMAP $=$ Dry mass of the aerial part (g); RDM = Root dry mass (g).

Besides these variables, we also determined the water relative level (WRL) and the integrity of the cell membrane through electrolyte extravasation (EE). To determine the WRL, we collected a leaf of each experimental unit, which were promptly weighted in a scale with a precision of $0.001 \mathrm{~g}(\mathrm{~W} 1)$, and then deposited for hydration for a period of 24 hours in plastic bags with $100 \mathrm{~mL}$ of distiled water. After this period, they were removed from water, weighted (W2), and stored in an air-ventilated muffle at $65{ }^{\circ} \mathrm{C}$ for 48 hours to obtain the dry mass (W3). The WRL was calculated through the methodology of Weatherley (1950), according to Equation 3 . The leaves were collected by morning to reduce the abiotic effects of radiation and temperature.

$$
W R L=\frac{W 1-W 3}{W 2-W 3} \times 100
$$

For the electrolyte extravasation, we collected, by experimental unit, eight leaf discs, each one of an area of 2.8 $\mathrm{cm}^{2}$, with the assistance of an iron driller, which were then washed and stored in Erlenmeyer vials with $50 \mathrm{~mL}$ of distiled water. The Erlenmeyer vials was sealed with foil paper and kept under a temperature of $25^{\circ} \mathrm{C}$ for 4 hours. After this period, the initial electric conductivity level in the means was measured $\left(X_{i}\right)$ with the assistance of a bench conductivity meter. Then the Erlenmeyer vials were submitted to the temperature of $90{ }^{\circ} \mathrm{C}$ for 2 hours in a forced-circulation muffle, and the electric conductivity level was measured again $\left(X_{f}\right)$. The electrolyte extravasation was expressed as an initial conductivity percentage for the electric conductivity level after the treatment for 2 hours at $90^{\circ} \mathrm{C}$ (Equation 4) (Scotti-Campos et al., 2013).

$$
\frac{X_{i}}{X_{f}} \times 100
$$

The data were evaluated through an analysis of variance by the $\mathrm{F}$ test at a level of 1 and $5 \%$ of probability, and the regression analysis was applied for the irrigation water salt concentrations and $\mathrm{H}_{2} \mathrm{O}_{2}$ levels with the assistance of the statistical software SISVAR version 5.3 (Ferreira, 2011).

\section{Results and Discussion}

The interaction between the water's salinity and the peroxide dosage factors significantly affected $(p<0.01)$ all studied variables, except for stem diameter (SD), which presented a significant interaction at $5 \%(\mathrm{p}<0.05)$. 
Table 2. Summary of the analysis of variance for the variables plant height $(\mathrm{PH})$, leaf number $(\mathrm{LN})$, stem diameter (SD), root length (RL), leaf area (LA), root and aerial part ratio (R/AP) of yellow passion fruit seedlings irrigated with water of different salinity levels for treatments with different $\mathrm{H}_{2} \mathrm{O}_{2}$ levels. Pombal, CCTA/UFCG, 2017

\begin{tabular}{llllllll}
\hline \multicolumn{7}{c}{ Mean Square } \\
\hline SV & GL & PH & LN & SD & RL & LA & R/PA \\
\hline Salinity (S) & 4 & $2025.88^{* *}$ & $26.73^{* *}$ & $1.92^{* *}$ & $129.02^{* *}$ & $34719311.9^{* *}$ & $0.0175^{* *}$ \\
Peroxide (P) & 2 & $305.45^{* *}$ & $17.50^{* *}$ & $0.40^{\mathrm{ns}}$ & $19.91^{\mathrm{ns}}$ & $7018131.6^{* *}$ & $0.027^{* *}$ \\
$\mathrm{~S} \times \mathrm{P}$ & 8 & $318.22^{* *}$ & $17.48^{* *}$ & $0.51^{*}$ & $35.78^{* *}$ & $8626645.9^{* *}$ & $0.017^{* *}$ \\
Block & 3 & $3.44^{\mathrm{ns}}$ & $2.14^{\mathrm{ns}}$ & $0.09^{\mathrm{ns}}$ & $8.52^{\mathrm{ns}}$ & $109471^{\mathrm{ns}}$ & $0.00062^{\mathrm{ns}}$ \\
\hdashline $\mathrm{CV}(\%)$ & 10.72 & 12.88 & 12.28 & 14.32 & 6.80 & 18.61 \\
Mean & 28.02 & 12.76 & 3.52 & 22.04 & 4865.37 & 0.258 \\
\hline Note. $* *$ \\
significant (p $>0.05)$, Source of Variation (SV), Coefficient of variation (CV).
\end{tabular}

For plant height, the absence of peroxide and the use of $15 \mu$ mol caused linear decreases that corresponded to 60.16 and $64.74 \%$, respectively, between the greatest $\left(4.3 \mathrm{dS} \mathrm{m}^{-1}\right)$ and the lower $\left(0.3 \mathrm{dS} \mathrm{m}^{-1}\right)$ salinity level (Figure 1A). Nevertheless, the concentration of $5 \mu \mathrm{mol}$ of $\mathrm{H}_{2} \mathrm{O}_{2}$ presented a quadratic behavior, whose greater plant height value $(28.05 \mathrm{~cm})$ was obtained when the plants were irrigated with a water sample of $2.3 \mathrm{dS} \mathrm{m}^{-1}$. This adjustment under stress conditions at the concentration of $5 \mu \mathrm{mol}$ is probably caused by the activity increase of the ATPase enzyme, which incremented the relation of $\mathrm{K}$ to $\mathrm{Na}$, resulting in adaptation to $\mathrm{NaCl}$ stress (Gupta \& Huang, 2014).

Regarding stem diameter (Figure 1B), the absence of peroxide and the treatment with $15 \mu$ mol caused the respective reductions of 5.82 and $7.80 \%$ in each unitary increase of the irrigation water's salinity. However, as noticed for plant height, the concentration of $5 \mu \mathrm{mol}$ presented a quadratic behavior over the increase of the irrigation water's salinity, with a maximum point $(3.83 \mathrm{~mm})$ at $2.3 \mathrm{dS} \mathrm{m}^{-1}$.

Nonetheless, the yellow passion fruit tree is very demanding in water terms and sensitive to salinity stress, with a maximum salinity of $1.3 \mathrm{dS} \mathrm{m}^{-1}$ (Ayers \& Westcot, 1999; Mesquita, Rebequi, Cavalcante, \& Souto, 2012). Ergo, this behavior at the concentration of $5 \mu \mathrm{mol}$ of $\mathrm{H}_{2} \mathrm{O}_{2}$ can mitigate the depressive effect because, according to Kilic and Kahraman (2016), the $\mathrm{H}_{2} \mathrm{O}_{2}$ reduced the salt-induced inhibition at germination, reducing the salinity stress' detrimental effects in the development of barley plants induced to pre-germinative treatment with peroxide at $30 \mu \mathrm{mol}$.

The leaf sprouting of the yellow passion fruit seedlings was also affected by the interaction (salinity $\times \mathrm{H}_{2} \mathrm{O}_{2}$ ), which, at the absence of peroxide, was proven inversely proportional to the salt levels, with a reduction of 18 $\left(0.3 \mathrm{dS} \mathrm{m}^{-1}\right)$ to 10 leaves $\left(4.3 \mathrm{dS} \mathrm{m}^{-1}\right)$, which corresponds to a decrease of $44.71 \%$ (Figure $\left.1 \mathrm{C}\right)$. On the other hand, the use of peroxide at the concentrations of 5 and $15 \mu \mathrm{mol}$ resulted in a quadratic behavior, with a maximum leaf number point at the concentration of 1.7 and $1.5 \mathrm{dS} \mathrm{m}^{-1}$, with 12 and 14 leaves, respectively. 

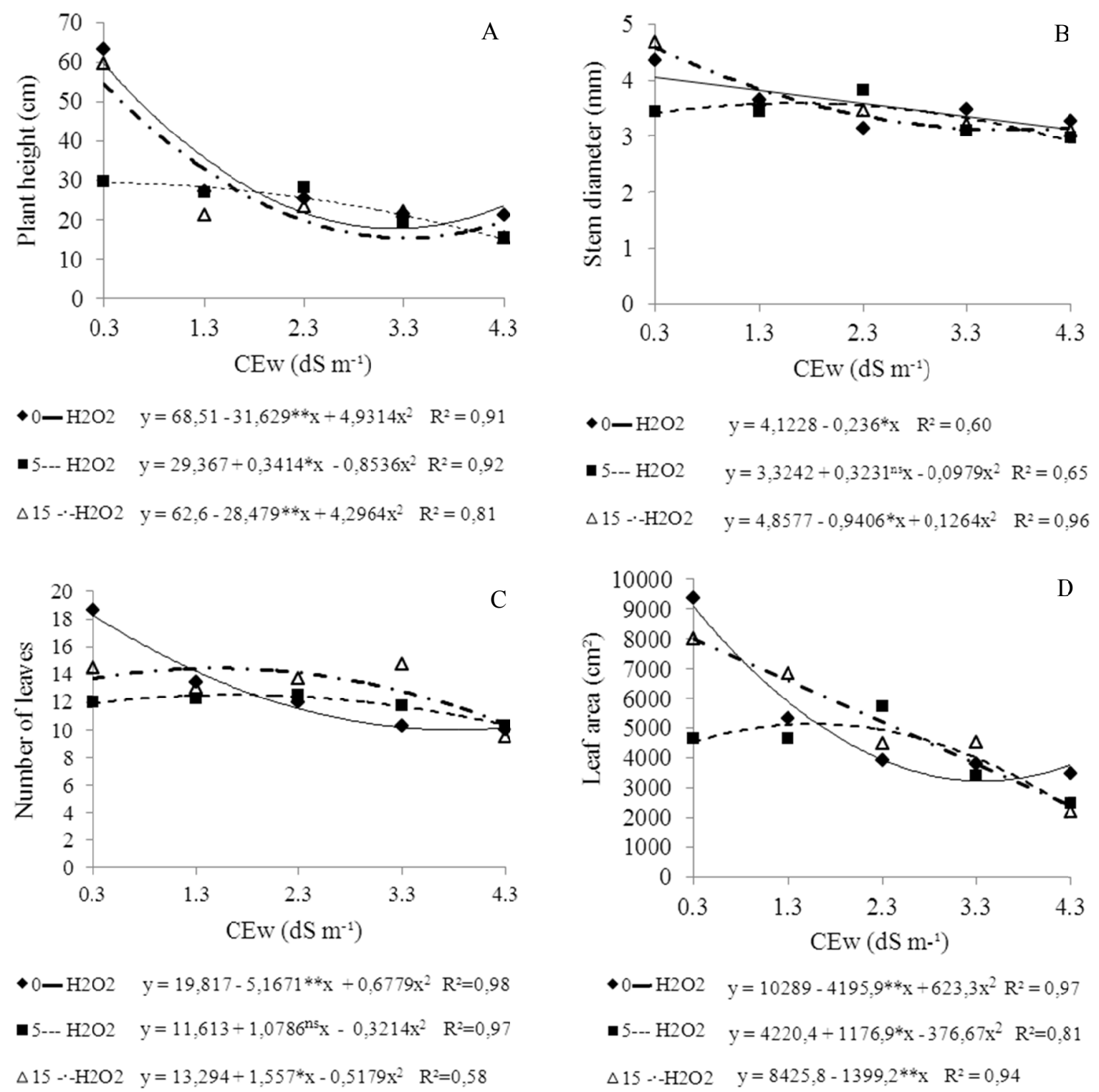

$$
\begin{array}{ll}
\bullet 0-\mathrm{H} 2 \mathrm{O} 2 & \mathrm{y}=19,817-5,1671 * * x+0,6779 \mathrm{x}^{2} \quad \mathrm{R}^{2}=0,98 \\
\text {-5--- } \mathrm{H} 2 \mathrm{O} 2 & \mathrm{y}=11,613+1,0786^{\mathrm{ns}} \mathrm{x}-0,3214 \mathrm{x}^{2} \quad \mathrm{R}^{2}=0,97 \\
\Delta 15-\cdot \mathrm{H} 2 \mathrm{O} 2 & \mathrm{y}=13,294+1,557^{*} \mathrm{x}-0,5179 \mathrm{x}^{2} \quad \mathrm{R}^{2}=0,58
\end{array}
$$$$
\Delta 15--\mathrm{H} 2 \mathrm{O} 2 \quad \mathrm{y}=8425,8-1399,2 * * \mathrm{x} \quad \mathrm{R}^{2}=0,94
$$

Figure 1. Plant height (A), stem diameter (B), leaf number (C), and leaf area (D) of yellow passion fruit seedlings irrigated with water samples of different electric conductivity levels for treatments with different $\mathrm{H}_{2} \mathrm{O}_{2}$ concentrations. Pombal, CCTA/UFCG, 2017

The seedlings' leaf area decreased in the absence of $\mathrm{H}_{2} \mathrm{O}_{2}$ and in the concentration of $15 \mu \mathrm{mol}$, with unitary reductions of 14.62 and $17.47 \%$ with the increase of the salinity levels, respectively (Figure 1D). However, at the $\mathrm{H}_{2} \mathrm{O}_{2}$ concentration of $5 \mu \mathrm{mol}$, the leaf area increased from $4539.57 \mathrm{~cm}^{2}$ under salinity $\left(0.3 \mathrm{dS} \mathrm{m}^{-1}\right)$ and reaching its greatest value of $5139.16 \mathrm{~cm}^{2}$ at the electric conductivity of $1.6 \mathrm{dS} \mathrm{m}^{-1}$.

According to Taiz et al. (2017), the salt accumulation in the plants can interfere both with the leaf sprouting and expansion. Therefore, Ribeiro, Seabra Filho, Moreira, Souza, and Menezes (2013), studying the effect of salt water on the initial growth of yellow passion fruit seedlings, also reported an inversely proportional reduction of the number of leaves and of the leaf area to the salt level. We can infer that both the increase of salts and of $\mathrm{H}_{2} \mathrm{O}_{2}$ caused reductions on the aerial part in response to the osmotic adjustment caused by stress conditions as a way to reduce water loss by transpiration. A similar effect was reported by Silva et al. (2016), who used concentrations of $15 \mu \mathrm{mol} \mathrm{L}{ }^{-1}$ upwards and got inferior values for the variables of plants not treated with $\mathrm{H}_{2} \mathrm{O}_{2}$. Nonetheless, something remarkable in this work was that the $\mathrm{H}_{2} \mathrm{O}_{2}$ dosage of $5 \mu \mathrm{mol}$ caused a tolerance increase for the passion fruit seedlings' leaf area. 
Similarly, the root length (Figure 2A) was inversely proportional to the salt levels in the control treatment (0 $\mu \mathrm{mol}$ of $\mathrm{H}_{2} \mathrm{O}_{2}$ ) and at the $\mathrm{H}_{2} \mathrm{O}_{2}$ concentration of $15 \mu \mathrm{mol}$ equipotent to 14.53 and $39.86 \%$ between 4.3 and $0.3 \mathrm{dS}$ $\mathrm{m}^{-1}$, as the $\mathrm{H}_{2} \mathrm{O}_{2}$ concentration of $5 \mu$ mol's maximum point was achieved at the concentration of $1.9 \mathrm{dS} \mathrm{m}^{-1}$, with a root length of $24.51 \mathrm{~cm}$. Silva et al. (2016) restated that small concentrations of hydrogen peroxide act intracellularly, activating the vegetable's defense mechanisms and promoting tolerance, a statement that agrees with what was seen herein at the $5 \mu \mathrm{mol}$ peroxide concentration.
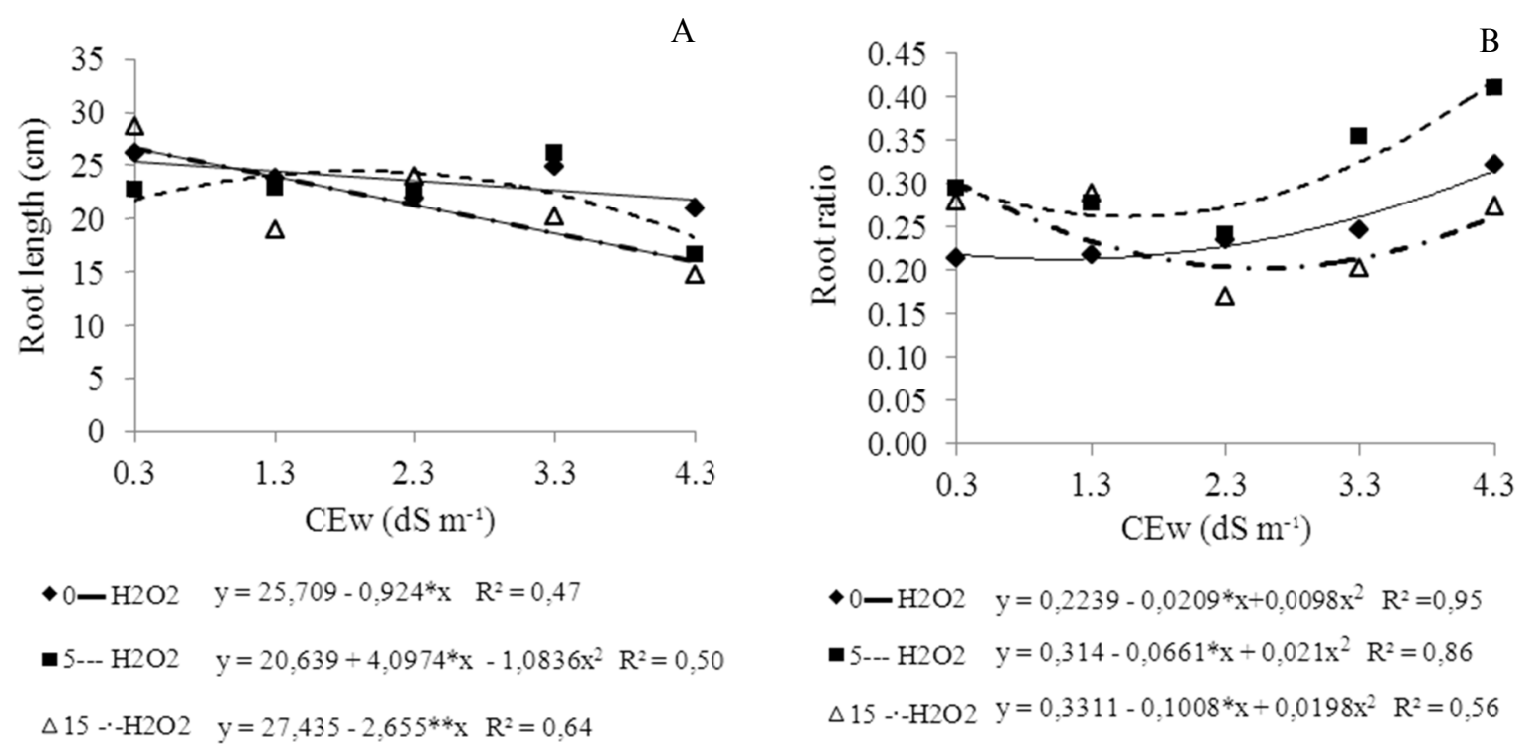

Figure 2. Root length (A) and root/aerial part ratio (B) of yellow passion fruit seedlings irrigated with water samples of different electric conductivity levels for treatments with different $\mathrm{H}_{2} \mathrm{O}_{2}$ concentrations. Pombal,

CCTA/UFCG, 2017

Consequently, the root/aerial part ratio was significantly afected by the interaction (peroxide and water salinity concentrations). We noticed a directly proportional increase of the root/aerial part ratio to the addition of salts in the water of the control treatment (11\%), while the treatments with 5 and $15 \mu \mathrm{mol}$ of $\mathrm{H}_{2} \mathrm{O}_{2}$ increased the root/aerial part ratio after $2.3 \mathrm{dS} \mathrm{m}^{-1}$ up to the greatest salinity level, which was greater in the treatment with 5 $\mu \mathrm{mol}$ of $\mathrm{H}_{2} \mathrm{O}_{2}(53 \%)$ in comparison to the $15 \mu \mathrm{mol}$ treatment (29\%) (Figure 2B).

Table 3 presents the interactive effect to all listed variables, except for the electrolyte extravasation (EE) variable, which affected the irrigation water salinity factor only when studied separately $(\mathrm{p}<0.01)$.

Table 3. Summary of the analysis of variance for the variables leaf, stem, and root dry mass (LDM, SDM, and RDM), total dry mass (TDM), water relative level (WRL), electrolyte extravasation (EE), and Dickson quality index (DQI) of yellow passion fruit seedlings irrigated with water samples of different salinity levels for treatments with different $\mathrm{H}_{2} \mathrm{O}_{2}$ concentrations. Pombal, CCTA/UFCG, 2017

\begin{tabular}{|c|c|c|c|c|c|c|c|c|}
\hline \multicolumn{9}{|c|}{ Mean Square } \\
\hline SV & GL & LDM & SDM & RDM & TDM & WRL & EE & DQI \\
\hline Salinity (S) & 4 & $2.297 * *$ & $0.936^{* *}$ & $0.290^{* *}$ & $8.778^{* *}$ & $109.694 * *$ & $122.21^{* *}$ & $0.016^{* *}$ \\
\hline Peroxide(P) & 2 & $0.598 * *$ & $0.507 * *$ & $0.100^{* *}$ & $3.140^{* *}$ & $51.630^{\mathrm{ns}}$ & $11.271^{\mathrm{ns}}$ & $0.0122 * *$ \\
\hline $\mathrm{S} \times \mathrm{P}$ & 8 & $0.469 * *$ & $0.295 * *$ & $0.075^{* *}$ & $2.032 * *$ & $65.512 * *$ & $25.984^{\mathrm{ns}}$ & $0.0056^{* *}$ \\
\hline Block & 3 & $0.024^{\mathrm{ns}}$ & $0.019^{\text {ns }}$ & $0.012^{\mathrm{ns}}$ & $0.142^{\mathrm{ns}}$ & $17.607^{\mathrm{ns}}$ & $47.270^{\text {ns }}$ & $0.0013^{\text {ns }}$ \\
\hline$C V(\%)$ & & 26.33 & 33.46 & 32.48 & 28.29 & 6.08 & $24.49^{-1}$ & $28.59^{-}$ \\
\hline Mean & & 1.071 & 0.573 & 0.403 & 2.048 & 74.123 & 17.398 & 0.167 \\
\hline
\end{tabular}

Note. ${ }^{* *}$ significant at $1 \%$ of probability $(\mathrm{p}<0.01) ; *$ significant at $5 \%$ of probability $(\mathrm{p}<0.05) ;{ }^{\text {ns }}$ not significant $(\mathrm{p}>0.05)$, Source of Variation (SV), Coefficient of variation $(\mathrm{CV})$. 
The increase of the irrigation water's salinity significantly affected the phytomass build-up of the passion fruit plants, if we consider the leaf and stem dry mass (Figures $3 \mathrm{~A}$ and $3 \mathrm{~B}$, respectively), in the absence of peroxide, as well as in the concentration of $15 \mu \mathrm{mol}$ of $\mathrm{H}_{2} \mathrm{O}_{2}$, which presented inversely proportional decreases to the water's salinity. These decreases were of 63.04 and $80.97 \%$ for the leaves, and of 57.61 and $81.97 \%$ for the measure of the stems. However, the concentration of $5 \mu \mathrm{mol}$ of $\mathrm{H}_{2} \mathrm{O}_{2}$ increased the leaf dry mass in $36.39 \%$ up to $2 \mathrm{dS} \mathrm{m}^{-1}$, and the stem dry mass increased $12.76 \%$ up to the salt concentration of $1.5 \mathrm{dS} \mathrm{m}^{-1}$.

We can infer that hydrogen peroxide has some features that allow it to act as a secondary messenger: I) its production is easily ruled by different stimuli, especially through the NADPH-oxidases and peroxides; II) it is a small and relatively mobile molecule, able to transport information between different cell compartments; III) it can modulate flag activities of other components and reaction cascades, with different biological results, including the ones that cause its own synthesis (Petrov \& Van Breusegem, 2012), because, through the evaluated variables, we can notice that the application of peroxide up to the dosage of $5 \mu \mathrm{mol}$ promotes greater tolerance in plants irrigated with water samples of up to $2.3 \mathrm{dS} \mathrm{m}^{-1}$.

According to Schossler, Machado, Zuffo, Andrade, and Piauilino (2012), higher sodium concentrations also affect the translocation and synthesis of hormones from the roots to the aerial part, which causes leaf area and, consequently, aerial part dry phytomass loss. Similar results are presented by Mesquita et al. (2012) and Ribeiro et al. (2013), who employed greater salt concentrations in the irrigation water of yellow passion fruit seedlings. 

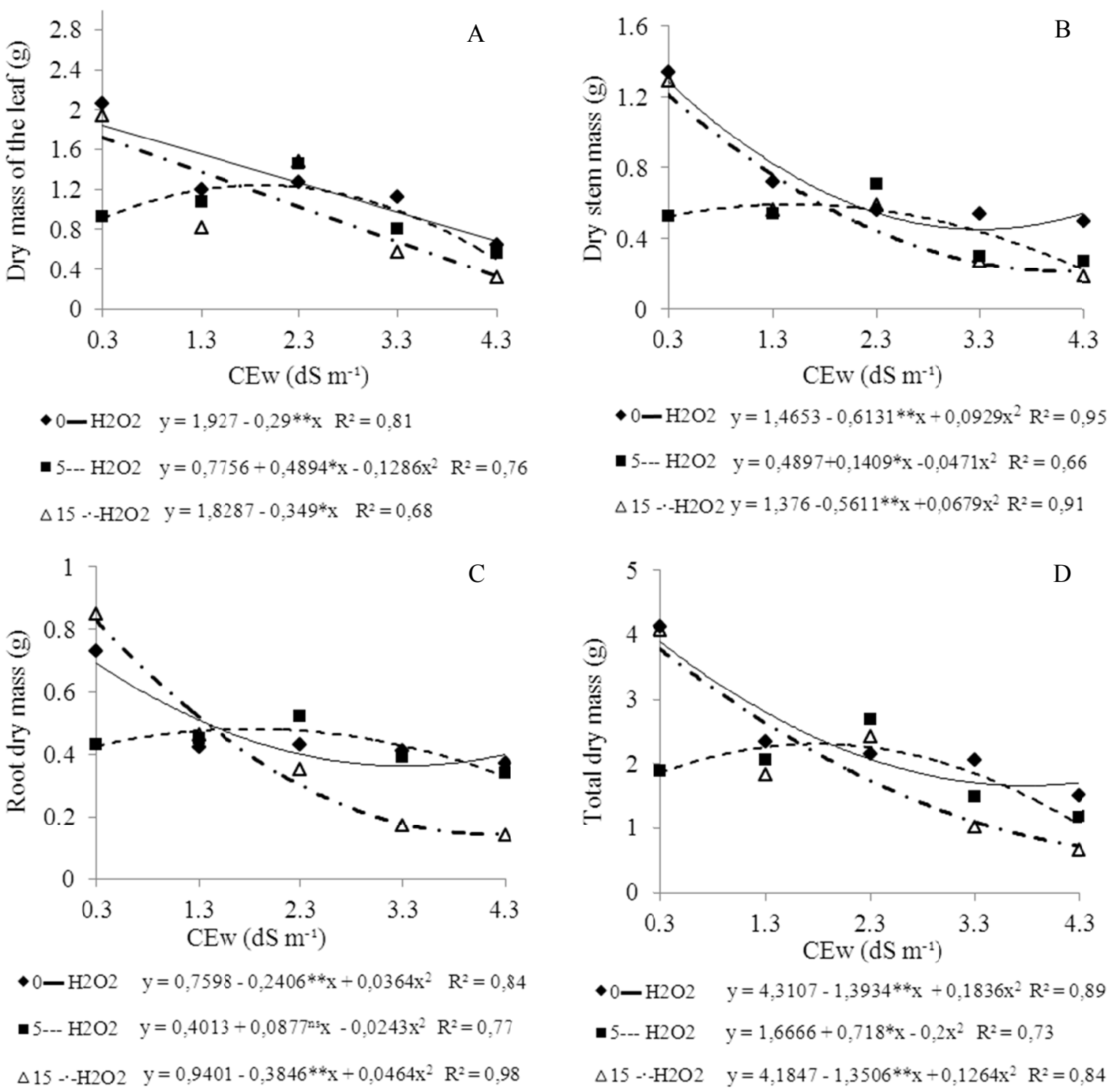

Figure 3. Leaf (A), stem (B), root (C), and total (D) dry mass of yellow passion fruit seedlings irrigated with saline water samples of different electric conductivity levels for treatments with different $\mathrm{H}_{2} \mathrm{O}_{2}$ concentrations

Pombal, CCTA/UFCG, 2017

Corroborating, the root (RDM) and total dry mass (TDM) presented a similar behavior with reductions at each saline unitary increase of 10.58 and $20.65 \%$ for RDM and 14.03 and $20.18 \%$ for TDM at the concentrations of 0 and $15 \mu \mathrm{mol}$ of $\mathrm{H}_{2} \mathrm{O}_{2}$ (Figures $3 \mathrm{C}$ and $3 \mathrm{D}$, respectively). However, the concentration of $5 \mu_{\mathrm{mol}}$ of $\mathrm{H}_{2} \mathrm{O}_{2}$ increased both the root and total phytomass up to the salt concentration of $1.8 \mathrm{dS} \mathrm{m}^{-1}$, corresponding to 13 and $24 \%$, respectively.

As for the water relative level in the plant, regardless of the $\mathrm{H}_{2} \mathrm{O}_{2}$ concentrations, the water relative content (WRC) was proven inversely proportional to salinity (Figure 4A), with reductions of $15.52,13.80$, and $11.56 \%$ at the concentrations of 0,5 , and $15 \mu \mathrm{mol}$ of $\mathrm{H}_{2} \mathrm{O}_{2}$, respectively, to the point in which they decreased from 80.9 , 76.8 , and $79.82 \%$ to $68.36,66.23$, and $70.59 \%$, respectively, in relation to the greater $\left(4.3 \mathrm{dS} \mathrm{m}^{-1}\right)$ and lower $(0.3$ $\mathrm{dS} \mathrm{m} \mathrm{m}^{-1}$ ) salinity level.

However, in spite of the inversely proportional decrease of the water content to the amount of salt, regardless of the use and concentrations of peroxide, we noticed that, with the peroxide concentration was inversely proportional to the damages caused by the salinity stress, since the concentration of $15 \mu \mathrm{mol}$ presented a lower reduction in comparison with all other treatments. Dias and Blanco (2010) state that one of the conditions 
offered by salinity is the reduction of water availability to the plants through the osmotic effect, which restrains the water's efficiency. However, the application of peroxide (5 and $15 \mu \mathrm{mol})$ favors such efficiency.
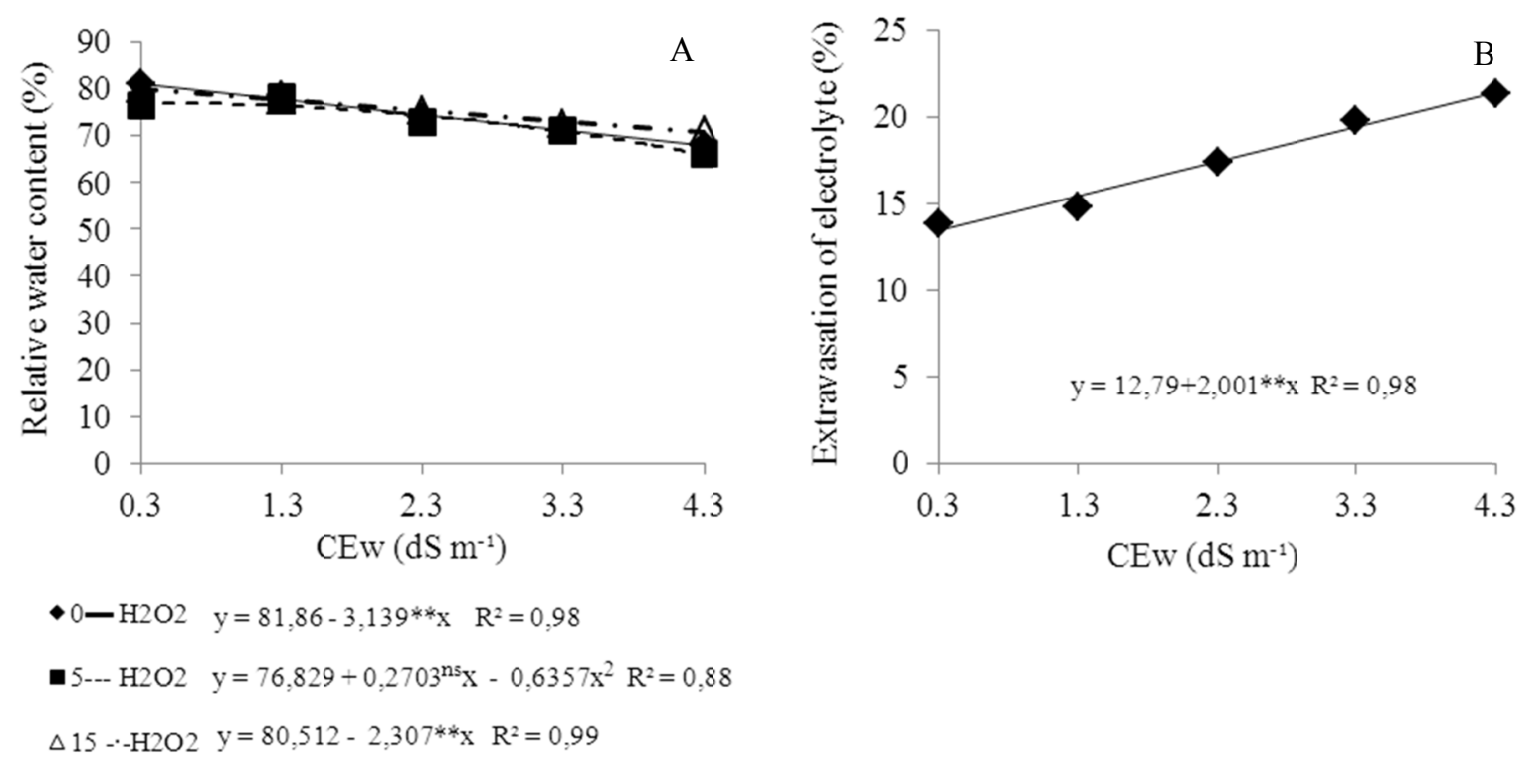

Figure 4. Water relative level (A) and electrolyte extravasation (B) for yellow passion fruit seedlings irrigated with saline water samples of different electric conductivity levels for treatments of different $\mathrm{H}_{2} \mathrm{O}_{2}$ concentrations.

Pombal, CCTA/UFCG, 2017

As for electrolyte extravasation (Figure 4B), the addition of salts in the irrigation water cause a linear increase of the EE, with an increase of $53.55 \%$ between the greater and the lower salinity level, which increased from 13.93 at the lower salinity level $\left(0.3 \mathrm{dS} \mathrm{m}^{-1}\right)$ to 21.39 in the plants irrigated with the greater salinity level $\left(4.3 \mathrm{dS} \mathrm{m}^{-1}\right)$. For Souza (2014), a salinity-tolerant vegetable controls its ion movement through the plasma membrane and through the tonoplast to maintain a low $\mathrm{Na}^{+}$concentration in the cytoplasm. We understand that damages caused to the cell membrane, indicated by the increase of electrolyte extravasation, results in hints of cell death caused by the excess of salts therein.

As it happens with the seedlings' phenological growth, the quality thereof was significantly affected by the interaction between the water's salinity and the hydrogen peroxide's foliar application, which resulted, both in the control treatment and with the use of $15 \mu \mathrm{mol}$ of $\mathrm{H}_{2} \mathrm{O}_{2}$, in decreases of the Dickson quality index to 20.67 and $73.32 \%$, respectively, which were registered between the greater $\left(4.3 \mathrm{dS} \mathrm{m}^{-1}\right)$ and lower $\left(0.3 \mathrm{dS} \mathrm{m}^{-1}\right)$ salinity level (Figure 5). However, although the peroxide concentration of $15 \mu \mathrm{mol}$ does not mitigate the depressive effects of salinity, the concentration of $5 \mu \mathrm{mol}$ of $\mathrm{H}_{2} \mathrm{O}_{2}$ increased the seedlings' quality in $36 \%$ up to the salinity level of $2.2 \mathrm{dS} \mathrm{m}^{-1}$, which declined afterwards. 


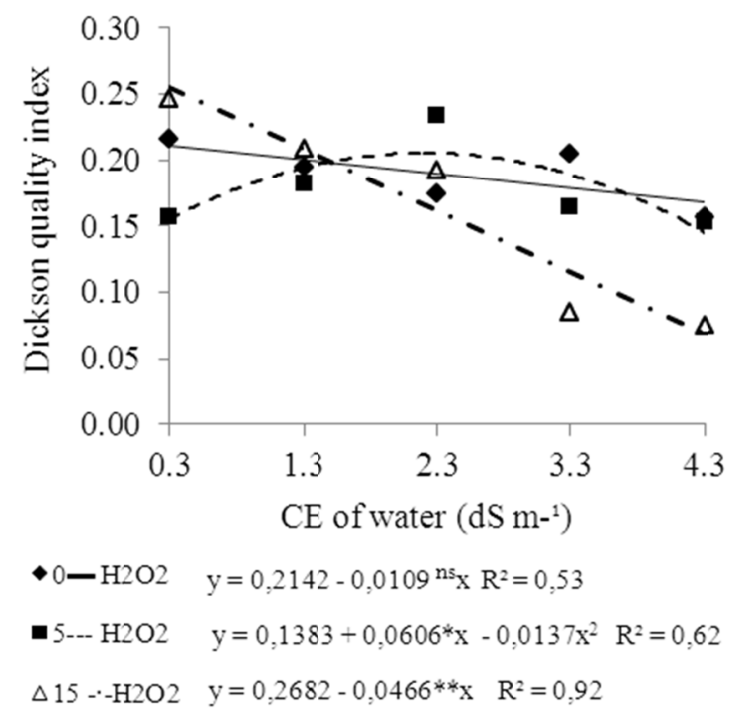

Figure 5. The Dickson quality index of yellow passion fruit seedlings irrigated with saline water samples of different electric conductivity levels for treatments of different $\mathrm{H}_{2} \mathrm{O}_{2}$ concentrations. Pombal, CCTA/UFCG, 2017

Furthermore, the increase of Dickson quality index values quantify the seedlings' quality standard (Costa, Durante, Nagel, Ferreira, \& Santos, 2011). Similar results related to salinity increase in yellow passion fruit seedlings that negatively affect the quality index were also found by Medeiros et al. (2016). Nonetheless, the use of peroxide at $5 \mu \mathrm{mol}$ in passion fruit seedlings probably made them insensitive to salinity $\left(>1.3 \mathrm{dS} \mathrm{m}^{-1}\right)$, or moderately sensitive thereto (1.3-3 $\mathrm{dS} \mathrm{m}^{-1}$ ), according to the results obtained herein (Ayers \& Westcot, 1999).

\section{Conclusions}

The hydrogen peroxide concentration of $5 \mu \mathrm{mol} / \mathrm{L}$ mitigated the harmful effect of salts up to $2 \mathrm{dS} \mathrm{m}^{-1}$.

Hydrogen peroxide mitigates the harmful effect of salinity. However, excessive concentration (15 $\mu \mathrm{mol})$ are harmful to yellow passion fruit seedlings.

The irrigation water's salinity affects the phenological growth and the quality of yellow passion fruit seedlings.

\section{Referências}

Agrianual. (2015). Anuário brasileiro de fruticultura. Santa Cruz do Sul, Gazeta.

Ayers, R. S., \& Westcot, D. W. A. (1999). A qualidade da água na agricultura (2nd ed.). Campina Grande, UFPB.

Campos, V. B., Fogaça, T. S., Almeida, W. L. A., Barbosa, J. A., Oliveira, M. R. T., Gondim, S. C., \& Cavalcante, L. F. (2013). Caracterização física e química de frutos de maracujá-amarelo comercializados em Macapá, Amapá. Revista Brasileira de Produtos Agroindustriais, 15(1), 27-33. https://doi.org/10.15871/ 1517-8595/rbpa.v15n1p27-33

Costa, E., Durante, L. G. Y., Nagel, P. L., Ferreira, C. R., \& Santos, A. (2011). Qualidade de mudas de berinjela submetida a diferentes métodos de produção. Revista Ciência Agronômica, 42(4), 1017-1025. https://doi.org/10.1590/S1806-66902011000400026

Dias, N. S., \& Blanco, F. F. (2010). Efeito dos sais no solo e nas plantas. In H. R. Gheyi, N. S. Dias, \& C. F. Lacerda (Eds.), Manejo da salinidade na agricultura: Estudos básicos e aplicados. Fortaleza, INCTA Sal.

Dias, T. J., Cavalcante, L. F., Leon, M. J., Santos, G. P., \& Albuquerque, R. P. F. (2011). Produção do maracujazeiro e resistência mecânica do solo com biofertilizante sob irrigação com águas salinas. Revista Ciência Agronômica, 42(3), 644-651. https://doi.org/10.1590/S1806-66902011000300010

Dickson, A., Leaf, A. L., \& Hosner, J. F. (1960). Quality appraisal of white spruce and white pine seedling stock in nurseries. The Forest Chronicle, 36(1), 10-13. https://doi.org/10.5558/tfc36010-1 
Faleiro, F. G., Junqueira, N. T. V., \& Braga, M. F. (2008). Pesquisa e desenvolvimento do maracujá. In A. C. S. Albuquerque, \& R. C. Silva (Eds.), Agricultura tropical: Quatro décadas de inovações tecnológicas, institucionais e politicas (1st ed.). Brasília: Embrapa.

Ferreira, D.F. (2011). Sisvar: A computer statistical analysis system. Ciência e Agrotecnologia, 35(6), 1039-1042. https://doi.org/10.1590/S1413-70542011000600001

Gondim, F. A., Gomes Filho, E., Marques, E. C., Prisco, J. T. (2011). Efeitos do $\mathrm{H}_{2} \mathrm{O}_{2}$ no crescimento e acúmulo de solutos em plantas de milho sob estresse salino. Revista Ciência Agronômica, 42(2), $373-381$. https://doi.org/10.1590/S1806-66902011000200016.

Gupta, B., Huang, B. (2014). Mechanism of Salinity Tolerance in Plants: Physiological, Biochemical, and Molecular Characterization. International Journal of Genomics, 14, 1-18. https://doi.org/10.1155/2014/ 701596

IBGE. (2015). Anuário Estatístico do Brasil. Sistema IBGE de Recuperação Automática (SIDRA), Rio de Janeiro. Retrieved January 2, 2018, from http://www.sidra.ibge.gov.br

Kilic, S., \& Kahraman, (2016). A. The Mitigation Effects of Exogenous Hydrogen Peroxide when Alleviating Seed Germination and Seedling Growth Inhibition on Salinity-Induced Stress in Barley. Polish Journal of Environmental Studies, 25(3), 1053-1059. https://doi.org/10.15244/pjoes/61852

Medeiros, S. A. S., Cavalcante, L. F., Bezerra, M. A. F., Nascimento, J. A. M., Bezerra, F. T. C., \& Prazeres, S. S. (2016). Água salina e biofertilizante de esterco bovino na formação e qualidade de mudas de maracujazeiro amarelo. Irriga, 21(4), 779-795. https://doi.org/10.15809/irriga.2016v21n4p779-795

Mesquita, F. O., Rebequi, A. M., Cavalcante, L. F., \& Souto, A. G. L. (2012). Crescimento absoluto e relativo de mudas de maracujazeiro sob biofertilizante e águas salinas. Revista de Ciências Agrárias, 35(1), 222-239.

Nunes, J. C., Cavalcante, L. F., Pereira, W. E., Lima Neto, A. J., Silva, J. A., \& Oliveira, F. F. (2016). Seedlings of yellow passion fruit in soils degraded by salts treated with bovine biofertilizer. Cientifica, 44(1), 91-101. https://doi.org/10.15361/1984-5529.2016v44n1p91-101

Petrov, V. D., \& Van Breusegem, F. (2012). Hydrogen peroxide-a central hub for information flow in plant cells. AoB PLANTS, invited review. https://doi.org/10.1093/aobpla/pls014

Ribeiro, A. A., Seabra Filho, M., Moreira, F. J. C., Souza, M. C. M. R., \& Menezes, A. S. (2013). Crescimento inicial do maracujazeiro amarelo irrigado com água salina em dois substratos. Revista Verde de Agroecologia e Desenvolvimento Sustentável, 8(3), 133-242.

Sá, F. V. S., Mesquita, E. F., Bertino, A. M. P., Costa, J. D., \& Araújo, J. C. (2015). Influência do gesso e biofertilizante nos atributos químicos de um solo salino-sódico e no crescimento inicial do girassol. Irriga, 20(1), 46-59. https://doi.org/10.15809/irriga.2015v20n1p46

Schmildt, E. R., Oliari, L. S., Schmildt, O., Alexandre, R. S., \& Pires, F. R. (2016). Determinação da área foliar de Passiflora mucronata a partir de dimensões lineares do limbo foliar. Revista Agro@mbiente On-Line, 10(4), 351-357. https://doi.org/10.18227/1982-8470ragro.v10i4.3720

Schossler, T. R., Machado, D. M., Zuffo, A. M., Andrade, F. R., \& Piauilino, A. C. (2012). Salinidade: Efeitos na fisiologia e na nutrição mineral de plantas. Enciclopédia Biosfera, 8(15), 1564-1578.

Scotti-Campos, P., Pham-Thi, A.-T., Semedo, J. N., Pais, I. P., Ramalho, J. C., \& Matos, M. C. (2013). Physiological responses and membrane integrity in three Vigna genotypes with contrasting drought tolerance. Emirates Journal of Food and Agriculture, 25, 1002-1013. https://doi.org/10.9755/ejfa.v25i12. 16733

Silva, E. M., Lacerda, F. H. D., Medeiros, A. S., Souza, L. P., \& Pereira, F. H. F. (2016). Métodos de aplicação de diferentes concentrações de $\mathrm{H}_{2} \mathrm{O}_{2}$ em milho sob estresse salino. Revista Verde de Agroecologia e Desenvolvimento Sustentável, 11(3), 1-7. https://doi.org/10.18378/rvads.v11i3.4343

Silveira, J. A. G., Silva, S. L. F., Silva, E. N., \& Viégas, R. A. (2016). Mecanismos biomoleculares envolvidos com a resistência ao estresse salino em plantas. In H. R. Gheyi, N. S. Dias, C. F. Lacerda, \& E. Gomes Filho (Eds.), Manejo da salinidade na agricultura: Estudos básicos e aplicados (2nd ed.). INCTsal, Fortaleza.

Souza, M. C. M. R. (2014). Efeitos da salinidade sobre o desenvolvimento vegetativo do noni sob duas condições ambientais, na ausência e presença de composto orgânico (Tese de Doutorado em Engenharia Agrícola, Universidade Federal do Ceará, Fortaleza). 
Taiz, L., Zeiger, E., Moller, I. M., \& Murphy, A. (2017). Fisiologia e Desenvolvimento Vegetal (6th ed.). Porto Alegre, Artmed.

Weatherley, P. E. (1950). Studies in the water relations of the cotton plant: The field measurements of water deficits in leaves. New Phytologist, 49(1), 81-97. https://doi.org/10.1111/j.1469-8137.1950.tb05146.x

Willadino, L., \& Camara, R. T. (2010). Tolerância das plantas à salinidade: Aspectos físiológicos e bioquímicos. Enciclopédia Biosfera, 6(11), 2-21.

\section{Copyrights}

Copyright for this article is retained by the author (s), with first publication rights granted to the journal.

This is an open-access article distributed under the terms and conditions of the Creative Commons Attribution license (http://creativecommons.org/licenses/by/4.0/). 